\title{
STRATEGIES FOR \\ CONSTRUCTING SPATIAL REPRESENTATIONS USED BY BLIND AND SIGHTED SUBJECTS
}

\author{
Magdalena SZUBIELSKA \\ The John Paul II Catholic University of Lublin \\ Lublin, Poland \\ E-mail: magdasz@kul.pl
}

\begin{abstract}
The study was designed to investigate imagery strategies used by blind and sighted individuals and their ability to operate spatial representations. Performance accuracy in the imagery tasks was confirmed to be similar in the blind individuals with no visual memories and in the sighted subjects. On the other hand, the findings showed differences in preferred imagery strategies. The sighted, more often than the blind subjects, used the strategy of visualizing spatial matrices. The blind subjects applied a tapping strategy more often than the sighted ones. Additional analysis focused on the function of working memory systems in processing spatial stimuli by the blind and sighted subjects.
\end{abstract}

Key words: imagery strategies, blindness, spatial image, visual image

Research involving blind subjects is a significant source of information for cognitive psychology, as it explains the importance of visual experience in the human cognitive process. Such analyses contribute, among other things, to a better understanding of the way in which spatial information is processed and represented in the mind. Unfortunately, literature discussing the role of visual experiences in the function of spatial imagination contains contradictory opinions (for a review see: Cattaneo, Vecchi, 2011; Cattaneo et al., 2008). Some studies have suggested that visual experience is critical for effective performance of operations involving imagery (e.g., Vanlierde, Wanet-Defalque, 2005), while other experiments have demonstrated that

Acknowledgments: This study was supported by Ministry of Science and Higher Education of the Republic of Poland; Grant \#NN106064235. blind individuals are as effective in operating images as sighted subjects (e.g., Vanlierde, Wanet-Defalque, 2004), or may even outperform them in such tasks (e.g., Noordzij, Zuidhoek, Postma, 2007). The issue is further complicated as various spatial skills are interrelated, therefore, delays in imagery skills frequently identified in blind individuals are not caused simply by a deficit in visual experience (Koustriava, Papadopoulos, 2012; see also: Schmidt et al., 2013). Long and Giudice (2010) also contributed to the in-depth discussion of why differences may or may not occur between blind and sighted people (in the field of orientation and mobility).

Studies reporting contradictory results may be explained by taking into account whether the adopted experimental procedure envisaged the use of visual or spatial images (these two aspects of imagery-related

DOI: $10.21909 /$ sp.2014.04.666 
performance have been analyzed, e.g., by Cornoldi, Vecchi, 2003). If a task invokes a visual image in the sense of Kosslyn (1994), i.e. an analogical representation is maintained in a visual buffer, sighted individuals score higher than blind subjects (provided that the task does not include incongruent stimuliin such a case, visual images employed by the sighted persons constituted a distractor, like in the example of the somatic rubber hand illusion: Petkova, Zetterberg, Ehrsson, 2012). On the other hand, if a task may be solved by employing amodal spatial image, which may be based on visual, tactile or auditory modalities as well as verbal input (Loomis, Klatzky, Giudice, 2013, see also: PascualLeone, Hamilton, 2001), blind individuals may show equally successful performance as their sighted counterparts.

Contradictory experiment results may also originate from the differences in employed research methods. Task characteristics provide blind subjects with an option to use preferred imagery strategies, which may compensate for the lack of visual experience. Adults with no visual experience (congenitally blind or early blind) create images at least as accurately as those created by sighted individuals, if they examine an auditory (Arno et al., 2001) or haptic spatial stimulus (Heller, 1989; Postma et al., 2007; Withagen et al., 2012), as these operations involve using their senses on a daily basis to assess spatial properties of the environment.

The necessity to use an external reference framework may be a variable moderating results of studies focusing on blind subjects' imagery-related performance. Sighted subjects, and to a degree, late blind individuals, seem to create an allocentric representation only a few seconds after encountering spa- tial stimuli, whereas, congenitally blind and early blind subjects are likely to encode the space in the form of egocentric representations (Pasqualotto et al., 2013; Postma et al., 2008). Pasqualotto and Proulx (2012) claimed that allocentric representation contains information relating to distances between objects in space, therefore, it may be recognized as more complex than an egocentric representation, which is based on bodycentred signals and movements. The same authors also emphasized that, if adequately trained, individuals without visual experience may learn to use an allocentric reference framework, yet, it is unlikely these will ever become their preferred representations. The use of an egocentric reference framework explains why blind individuals remember the space in the form of routes (contrary to sighted subjects who use survey-like representations) (Millar, 1975; Noordzij, Zuidhoek, Postma, 2006). The application of complex allocentric mental imagery representations may also explain the fact that complicated spatial tasks are solved more successfully by individuals with visual experience than by subjects without visual memories, while such differences are not found in simple tasks (Cornoldi et al., 1993; Vecchi, 1998). Yet, the role of both visual experience and task difficulty level in operating mental images is unclear, e.g., the study by Toroj and Szubielska (2011) showed that late blind subjects performed more accurately than those blind since birth in a task involving tactile comparison of shapes retaining the same position, while the comparison of rotated shapes did not differ in both study groups.

Good results demonstrated by early blind subjects in imagery tasks may also be facilitated by gradual presentation of subsequent elements of a stimulus, as this routine is con- 
sistent with natural encoding of haptic and verbal inputs from the environment. Thus, the experimental method employed by Vanlierde and Wanet-Defalque (2004) allowed subjects without visual experience to obtain high scores (similar performance was found in early blind, late blind and sighted subjects). During a trial, the experimenter verbally described 2D figures consisting of six elements and placed within a square grid comprising 36 squares. For each stimulus, a verbal sequence introduced each subsequent line that was followed by information of whether each consecutive square in the row was black (filled-in) or white (empty). Following the complete description, the subjects were provided with the axis against which they performed the symmetry recognition task - they identified the number of mirrored black squares (evaluating the socalled "concordance level"). The result was that nearly all the blind participants without visual experience (excluding one subject who reported to have created a mental image and tactile impressions) employed verbal strategies, which involved remembering coordinates (so-called "coordinate XY strategy"), while all the sighted and a majority of the late blind subjects visualized the figure (one late blind subject combined the latter with the coordinate XY strategy). Thus, visualization as a strategy for remembering a spatial pattern was favoured by individuals with visual experience, while subjects without visual experience preferred verbal information encoding as the most effective mental imagery strategy (see also: Cornoldi et al., 2009).

Other studies have shown that early blind and sighted individuals do not differ so much in terms of the frequency of employing specific strategies (e.g., Cornoldi et al., 2009), and that congenitally blind subjects con- struct spatial representations by employing strategies other than verbal ones: imagining a landmark position, and moving within the space (Schmidt et al., 2013) or touching the imagined object (Arditi, Holtzman, Kosslyn, 1988). A concept of supramodal representation suggests that tactile and motor strategies may play an important part in creating spatial images in blind individuals (Struiksma, Noordzij, Postma, 2009). No evidence for the dominating coordinate XY strategy in early blind subjects was shown by a study of brain activation (Vanlierde et al., 2003). Furthermore, if a verbal strategy was dominant in early blind subjects, a concurrent articulatory suppression task would impair the performance level in spatial processing tasks in this group to a greater extent than in the group of sighted participants, yet, this has not been supported by research findings (Vecchi, 1998). Interestingly, the performance in imagery tasks was equally impaired in congenitally blind and sighted subjects by the concurrent finger tapping task (Aleman et al., 2001). On the other hand, blind individuals have been found with superior abilities to remember verbal information (e.g., Hull, Mason, 1995; Raz et al., 2007; Röder, Rösler, Neville, 2001), which may facilitate verbal processing in working memory.

The design of the present study was based on the experiment by Vanlierde and WanetDefalque (2004); however, some changes were introduced in the experimental procedure. The specific differences between the study discussed here and the original experiment include: the introductory stage (before the presentation of experimental stimuli all subjects received a tactile board and six buttons to be placed on it, whereas in the original study the experimenters showed drawings to the sighted subjects, and the blind 
subjects were given a thermoform copy with equivalent patterns); the method of communicating that a square was filled in or empty (auditory information - sound of a drum or cymbal, whereas the original study used verbal information - "black" or "white"), method of informing the subjects about the next row (auditory information - a ring-tone, while the original study used verbal information - "first line", "second line", etc.), number of tasks (16 versus the original 24), patterns used in the experiment (rather than use shapes resembling certain letters, e.g., L, T, U - like some of those in the original design, the present study employed asemantic and asymmetric shapes, however the latter were not used in the case of concordance level assuming the value of 3 ). Moreover, half of the experimental tasks were supplemented with a concurrent task and this element was not present in the original design at all. The concurrent task was manipulated to load either the visuo-spatial (experiment 1a) or articulatory system of working memory (experiment 1b). Another new element, different from the original design, was the measurement of the capacity of working memory for verbal material, controlled in each subject. If sighted individuals employ a visualization strategy, and blind persons, with no visual memories, use a verbal coordinate XY strategy, then the strain imposed on the visuo-spatial system should make performance of the task more difficult for the sighted than for the blind subjects, while the strain imposed on the articulatory system should decrease the scores obtained by the blind to a larger extent than in the sighted subjects. Furthermore, working memory capacity for verbal material should positively correlate with the performance in the imagery task for the blind individuals only.

\section{METHOD}

Two experiments were conducted. Experiment la focused on a load imposed on the visuo-spatial system, and experiment $1 \mathrm{~b}$ investigated the impact of strain imposed on the articulatory system on the performance of spatial tasks by the blind and sighted subjects.

\section{Participants}

The study group consisted of 28 adults participating in a larger research project. The sighted controls were individually matched with the blind subjects in terms of gender, age and education (at least secondary in all cases). Blind subjects had, at most, light perception.

Experiment 1a was carried out with 8 blind subjects ( 4 females; 6 individuals were blind since birth, 1 person lost vision after the age of one, and 1 individual was blind since the age of 4; early blind subjects reported no visual memories) and 8 sighted persons. The mean age in both groups was, respectively: $\mathrm{M}=22.88$ years $(\mathrm{SD}=5.87) ; \mathrm{M}=23.13$ years $(\mathrm{SD}=4.52)$.

Experiment $1 \mathrm{~b}$ began with 8 blind subjects (4 females); two male subjects found the tasks too difficult and refused to continue. Hence, ultimately the study group consisted of 6 blind subjects ( 5 individuals were blind since birth, 1 person lost vision after the age of one and reported no visual memories) and 6 sighted persons. The mean age of the blind subjects was 23.67 years $(\mathrm{SD}=3.67)$ and the sighted participants, on average, were 24.67 years old $(\mathrm{SD}=3.44)$.

Each subject participated in only one experiment, either 1a or $1 \mathrm{~b}$. 


\section{Materials}

In both experiments, the stimuli were 16 matrices consisting of six elements, similar to those used by Vanlierde and WanetDefalque (2004), and located within a 36-element square grid. Each pattern was characterized in terms of the symmetry axis orientation and the concordance level (see Table 1). The concordance level could assume the values of $0,1,2$ or 3 and was defined by, "how many pattern elements were in corresponding positions in the different halves of the grid according to the specified grid axis" (Vanlierde, Wanet-Defalque, 2004, p. 208). Experiment 1a additionally used a set of 20 pairs of blocks with various shapes (see Szubielska, 2010).

\section{Procedure}

The experiments were conducted individually. They began with a verbal memory test a backward digit span task, which allowed for controlling working memory capacity. The relevant rate was the number of elements in a sequence, which the individual was able to recall correctly in reverse order. During the experiments, the sighted persons were blindfolded.

In the course of the familiarization procedure, the subjects tactually explored the board with tactile graphics showing a square grid with 36 elements and learned three audible signals for a new row (ring), empty square (cymbal) and filled-in square (drum). As an example, they also heard

Table 1. Characteristics of experimental material: Task order, presence of distractor, symmetry axis orientation and concordance level

\begin{tabular}{|c|c|c|c|}
\hline Task Order & Distractor & Symmetry Axis Orientation & $\begin{array}{c}\text { Concordance } \\
\text { Level }\end{array}$ \\
\hline 1 & No & Vertical & 1 \\
\hline 2 & Yes & Horizontal & 0 \\
\hline 3 & No & Horizontal & 3 \\
\hline 4 & Yes & Vertical & 2 \\
\hline 5 & No & Vertical & 2 \\
\hline 6 & Yes & Vertical & 3 \\
\hline 7 & No & Horizontal & 1 \\
\hline 8 & Yes & Horizontal & 1 \\
\hline 9 & No & Horizontal & 2 \\
\hline 10 & Yes & Vertical & 2 \\
\hline 11 & No & Horizontal & 3 \\
\hline 12 & Yes & Horizontal & 1 \\
\hline 13 & No & Horizontal & 0 \\
\hline 14 & Yes & Vertical & 0 \\
\hline 15 & No & Vertical & \\
\hline 16 & Yes & Vertical & \\
\hline
\end{tabular}


sounds for three matrices in accordance with the following formula: at one-second intervals, the signal for the row (top down) and six consecutive signals identifying filled-in or empty squares (left to right). Each matrix contained six filled-in squares. During the familiarization stage, the subjects could place six buttons on the tactile board, to mark the filled-in squares. The experimenter made sure the subjects understood the concept of symmetry axis and, while touching the matrix on the board, were able to specify how many pairs were mirrored according to either vertical or horizontal axis, thus, evaluating the concordance level.

During the experimental phase, 16 tasks were performed in fixed order (see Table 1) - the participants heard the sound signals "describing" the matrices. Half of the matrices were presented without a concurrent task, and the other half with a distractor task, which involved either searching for pairs of identical blocks tactilely (the blocks were arranged randomly on the table), engaging the visuo-spatial component of working memory (experiment 1a) or engaging the articulatory system by silent subtraction (each subject was given a random threedigit number and asked to "count down" each time decreasing the number by three; once the audible signal ended they were asked to provide the value which they managed to reach) (experiment 1b). Next the subjects were provided with the axis against which they were to evaluate the concordance level.

The experiments ended with an individual debriefing, where the subjects were asked to explain the method they used while performing the tasks.

\section{RESULTS}

\section{Spatial Abilities}

Performance accuracy in imagery tasks depending on working memory load and visual status are shown in Figure 1 (accuracy in experiment 1a) and Figure 2 (accuracy in experiment $1 b$ ).

In each experiment a mixed-model factorial ANOVA on accuracy data was performed for intra-object factor: working memory load (yes; no) and for inter-object factor: visual status (blind subjects; sighted subjects). In experiment 1a, no main effect was found for working memory load, $\mathrm{F}(1,14)=2.52, \mathrm{p}=$ .135 ; or visual status, $\mathrm{F}(1,14)=.00, \mathrm{p}=1.00$; similarly, interactions between the factors were not significant, $\mathrm{F}(1,14)=3.63, \mathrm{p}=.078$. In experiment $1 b$, the findings did not show the effect of working memory load, $\mathrm{F}(1,14)=$ $.04, \mathrm{p}=.838$, visual status, $\mathrm{F}(1,14)=.02, \mathrm{p}=$ .898 , or interaction of factors, $\mathrm{F}(1,14)=.04$, $\mathrm{p}=.838$. Additionally, the two experiments were compared in terms of task performance. The findings showed no differences between tasks performed without distractor, $\mathrm{t}(26)=$ $1.71, \mathrm{p}=.100$, or with distractor, $\mathrm{t}(26)=.14$, $\mathrm{p}=.888$. As a result, and because of the small groups of subjects participating in each experiment, further analyses were conducted for joint data obtained during both experiments, and by summing the results acquired for conditions with and without distractors.

\section{Verbal Memory}

On average, the blind subjects recalled in reverse order 10.36 digits $(\mathrm{SD}=2.31)$, which was significantly higher than the score ob- 


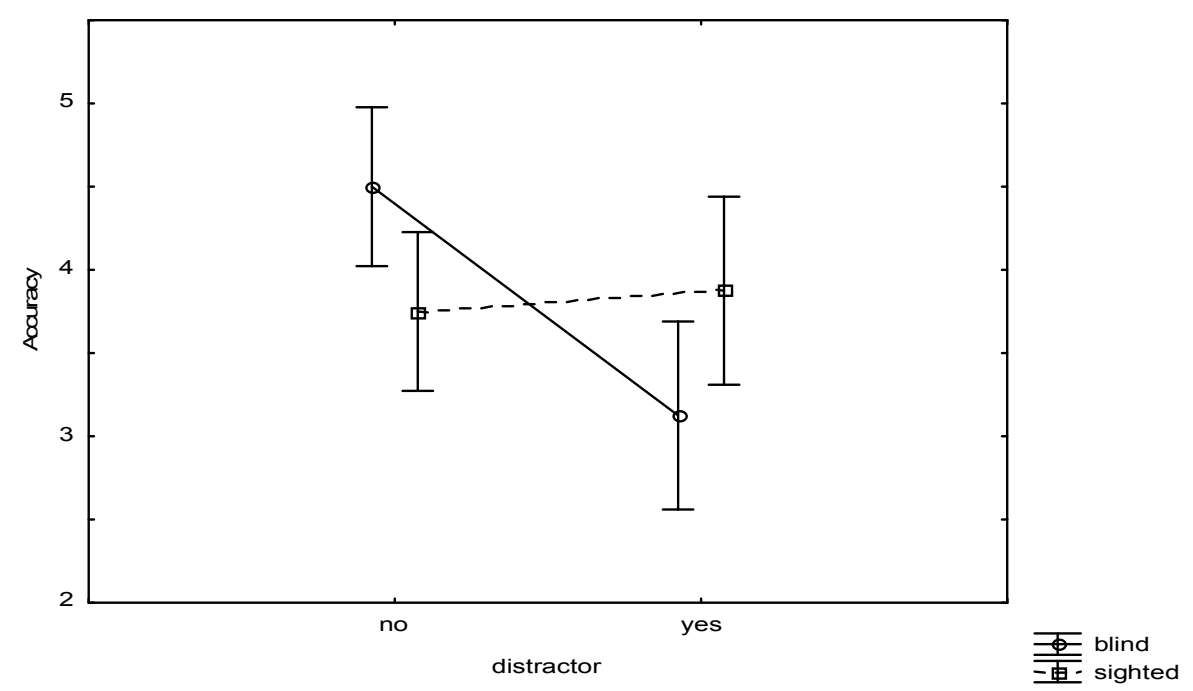

Figure 1. Accuracy in experiment 1a, focusing on load imposed on the visuo-spatial system. Error bars represent \pm 1.0 standard error of the mean

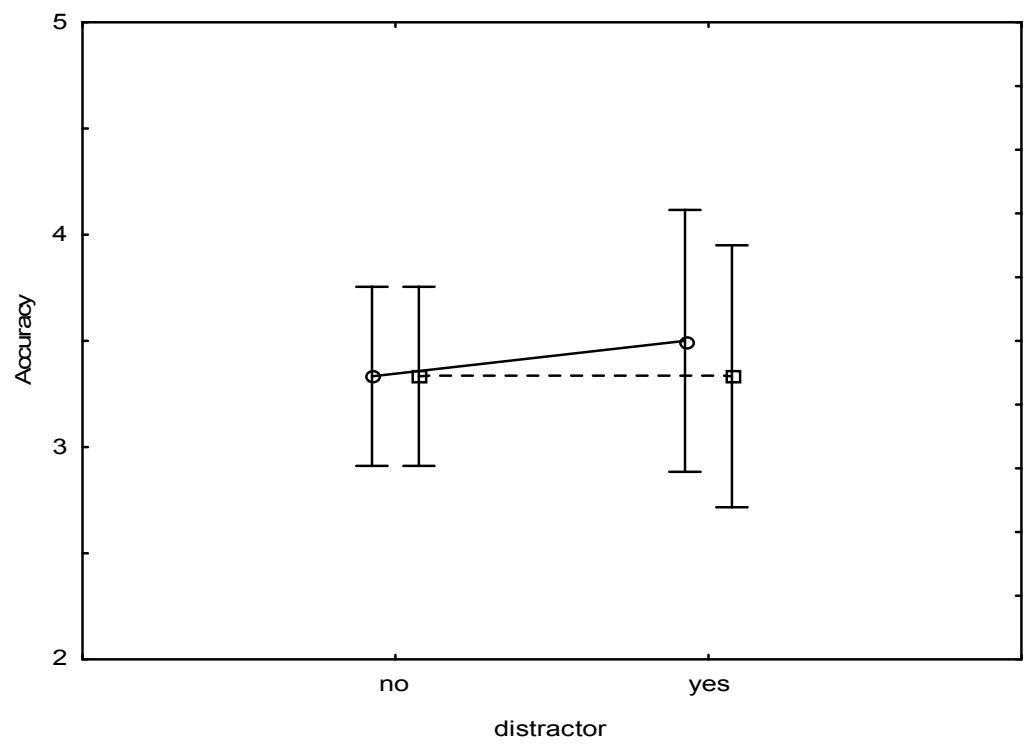

Figure 2. Accuracy in experiment $1 \mathrm{~b}$, focusing on load imposed on the articulatory system. Error bars represent \pm 1.0 standard error of the mean 
tained by the sighted individuals $\mathrm{M}=7.07$ $(\mathrm{SD}=1.14) ; \mathrm{t}=3.89, \mathrm{p}<.001$. Pearson's $\mathrm{r}$ test was used to calculate the correlation between backward digit span task and the overall result in the imagery task in the groups of blind and sighted subjects. In the group of blind subjects, the correlation was moderate, positive and marginally significant, $\mathrm{r}=.52 ; \mathrm{p}=$ .059 , and in the group of sighted subjects it was not significant $\mathrm{r}=.34 ; \mathrm{p}=.238$.

\section{Reported Mental Imagery Strategies}

The subjects' reports allowed for identifying three different strategies: visualization (e.g., "I imagined the grid with spatial properties, like in computer games; I imagined a filled-in square was accompanied with a flash, the square was blinking - and empty squares were not"; "I remembered what the figure looked like, I tried to see its shape"), coordinate XY (making use of the grid's coordinate system, e.g., "I remembered the layout with numbers"; "I memorized them as points of coordinates - which filled-in squares were in which row"), and tapping ("I imagined I was putting my fingers on the squares"; "I tapped along with my fingers"). One blind man admitted he was unable to describe how he had performed the task, and due to this he was disregarded in further analyses.

There were 13 participants ( 6 blind subjects) who used a single strategy, 13 participants ( 7 blind persons) who employed two, and 1 sighted person who used three strategies. Visualization as the sole strategy was employed by 5 sighted persons, 2 sighted and 4 blind participants used coordinate XY, and 1 blind person used tapping. A mixture of coordinate XY strategy and tapping was used by 4 blind persons, whereas, visualiza- tion and coordinate XY strategy were combined by 6 sighted subjects and 1 blind person (who lost vision at the age of 1 , and claimed to have performed the task "visually": "I imagined buttons on the board, how they would be positioned and what shape they would take").

Pearson's $\chi^{2}$ test (for expected frequencies below 5 with Yates' correction) was used to compare the frequency with which specific strategies were employed in the groups of blind and sighted subjects. The sighted, significantly more often than the blind subjects, used visualization $(85.71 \%$ vs. $7.69 \%), \chi^{2}=$ $16.43, \mathrm{p}<.001$, and the blind, significantly more often than the sighted subjects, used the tapping strategy $(61.54 \%$ vs. $7.14 \%), \chi^{2}=$ $6.69, \mathrm{p}=.010$. No differences were found between the blind and sighted subjects in terms of the frequency of using coordinate $X Y$ strategy $(84.62 \%$ vs. 64.29$), \chi^{2}=.59, \mathrm{p}=$ .444 . McNemar's $\chi^{2}$ test was used to compare the frequency with which specific strategies were used in each group of subjects. The frequency of employing strategies by the blind subjects was equal for coordinate $\mathrm{XY}$ and tapping, $\chi^{2}=.57, \mathrm{p}=.450$, and they reported having used coordinate $\mathrm{XY}, \chi^{2}=$ $8.10, p=.004$ and tapping, $\chi^{2}=4.00, p=.046$ more often than visualization. The sighted subjects used visualization and coordinate $\mathrm{XY}$ strategy equally, $\chi^{2}=.57, \mathrm{p}=.450$, and employed visualization, $\chi^{2}=9.09, \mathrm{p}=.003$ and coordinate $\mathrm{XY}, \chi^{2}=6.13, \mathrm{p}=.013$ more often than a tapping strategy.

\section{DISCUSSION}

The purpose of the paper was to investigate imagery strategies employed by blind persons without visual memories and sighted individuals as well as their ability to operate 
spatial representations. As in the original experiment by Vanlierde and Wanet-Defalque (2004), blind and sighted subjects achieved similar performance accuracy and differed in terms of the applied imagery strategies. However, the high consistency related to the application of only one imagery strategy - visual by the sighted and coordinate XY by the blind subjects - has not been confirmed. Based on the subjects' reports, it was established that approximately half of both the blind and sighted subjects used more than one strategy simultaneously.

Critical analysis of the study by Vanlierde and Wanet-Defalque (2004) raises doubts concerning some of the effects identified by these authors. Early blind participants informed the experimenters that the task given to them was similar to the "game of bowls" which is popular among blind persons. Possibly, the former recurring experience of the game allowed the subjects to practice the coordinate XY strategy. Moreover, the visualization strategy may have been imposed on the late blind and sighted subjects by the experimenters due to the adopted procedure - the figure on the grid was characterized by describing the location of the blackened squares (additionally, during the introductory stage, the experimenters showed drawings to the sighted subjects). Therefore, the findings reported by Vanlierde and Wanet-Defalque (2004) may have resulted from the fact that the congenitally blind participants were highly specialized in the coordinate XY strategy, and from the method of providing information about the figures, which emphasized the visual aspect of the matrix.

In the present study, in addition to visualization, the sighted subjects employed with equal frequency a coordinate XY strategy, and reported using a tapping strategy (which they applied significantly less frequently than visualization or coordinate XY strategy). This finding shows that they performed the imagery task both by employing visual images in the Kosslyn's sense (1994) (when they tried to envisage with their mind's eye the shape gradually appearing on the board: object visualizers), and by constructing, in their working memory, spatial images based on linguistic information (remembering the coordinates) or visual information (when they visualized the matrix, yet were not trying to imagine precisely the shape, but the selected filled-in points on the matrix, and spatial relations between them: spatial visualizers) (cf.: Kozhevnikov, Kosslyn, Shepard, 2005; Loomis et al., 2013). While performing the imagery task, according to their reports, the blind subjects used with equal frequency the coordinate $\mathrm{XY}$ and tapping strategies, which were also employed significantly more often than visualization. This shows that, while creating spatial images, blind persons apply verbal information (XY strategy) as extensively as tactile-motor imagery (tapping strategy). One early blind subject reported having visualized the matrices. Some authors assume, controversially, that congenitally blind people may have visual imagery (e.g., Bertolo et al., 2003), yet, this belief is criticized by other researchers (e.g., Kerr, Domhoff, 2004; Lopes da Silva, 2003). Importantly, the early blind male who reported the use of visualization strategies recounted the properties of spatial images which he had employed (cf.: Loomis et al., 2013). Additionally, he may have made a tacit assumption that creating spatial representation requires visual modality. Thus, the use of visual strategy reported by the early blind subject may be considered dubious. 
The sighted more often than the blind participants visualized the spatial stimuli, while the blind more often than the sighted subjects used tapping. The obtained effects are consistent with researchers' reports, saying that sighted individuals prefer an allocentric reference framework while congenitally blind and early blind persons prefer an egocentric framework (Pasqualotto, Proulx, 2012; Pasqualotto et al., 2013; Postma et al., 2008). The blind subjects employed a coordinate $\mathrm{XY}$ strategy as often as the sighted ones. Given the fact that the strategy puts a higher load on working memory, it can be assumed that the blind subjects relied on it to a greater extent than the sighted individuals, who may have treated it merely as support for their visualization strategy (cf.: Struiksma et al., 2009). Positive correlations (marginally significant) between working memory capacity and accuracy in performing imagery tasks were found only in the blind subjects. Additionally, the blind were found with better memory of verbal material than the sighted subjects (cf. Hull, Mason, 1995; Raz et al., 2007; Röder et al., 2001), which is linked with the capacity to retain more information in the articulatory system.

Consistent with the findings of Vecchi (1998), additional involvement of the articulatory system of working memory did not impair performance accuracy in imagery tasks in the sighted or blind subjects. Yet, based on additional information, it was assumed that the concurrent task engaging the articulatory system was more distractive for the blind subjects - two blind persons did not complete experiment $1 \mathrm{~b}$ because they were discouraged by the task where they were required to simultaneously remember a spatial pattern and perform subtraction silently. No evidence was found in the two study groups for distractive impact of the concurrent task engaging the visuo-spatial system (which contradicts the results of Aleman et al., 2001).

A lack of evidence demonstrating impact of the additional spatial and articulatory tasks may have resulted from the fact that, whether or not the subjects were asked to do the additional task, both the blind subjects and the sighted individuals were found with rather poor performance (i.e., majority scored less than $50 \%$ correct responses, except for experiment $1 \mathrm{a}$, where the blind subjects, in the conditions with no distractor, provided slightly more than $50 \%$ correct answers). Perhaps the task which was designed for the experiment and required the subjects to generate mental representation of the examined pattern was too difficult for them and placed too much strain on working memory. Due to this, the additional load of the second task did not significantly impair the accuracy of the constructed representations. Yet, it is hard to determine whether the difficulty of the task was critically impacted by the method of presenting information about the pattern - acoustic rather than verbal, or by the greater complexity of patterns in comparison to those used in the study by Vanlierde and Wanet-Defalque (2004). By comparison, in the latter study the average accuracy in solving the tasks (calculated for all the subjects) amounted to $60 \%$. It would be a worthwhile idea to investigate this issue in another experiment where, by design, these two variables (method of presentation and complexity of patterns) would be manipulated. Furthermore, it is possible that the additional task did not impact performance accuracy in the imagery task because no requirements were imposed on the subjects with regard to the speed of either the explo- 
ration of the specific shapes or the operation of subtracting. It is likely that each subject performed the task in a way that matched his or her capabilities, and avoided excessive strain on working memory. The limitations of the present experiments may also be explained by the small study groups. Yet, this is quite a common drawback of studies involving specialized populations. Experiments with blind persons tend to be conducted with small groups (e.g., Loomis et al., 2002). Many blind individuals, who were invited to participate in this study, refused to get involved and explained they were overstressed as a result of recent participation in a number of time-consuming and exhausting psychological experiments. Some individuals refused to participate as there was no financial compensation. Another limitation may have resulted from the design of the study, which was split into two experiments. More interesting findings could have been obtained during a study with a repeated measures design, with all participants performing tasks in the following conditions: with no load, and with strain imposed on both the articulatory and visuo-spatial systems. Despite that, as this study was part of a larger project, the author decided to limit the number of tasks and designed only two experiments.

In summary, if a task, due to its characteristics, may be performed by employing spatial images, blind individuals with no visual memories may be as effective as sighted people (in those kinds of tasks the latter probably employ both quite distinctive analogue visual images and less explicit spatial images, which take into account the relations between specific elements within the space: Loomis et al., 2013; cf.: Kozhevnikov et al., 2005). It was also demonstrated that the source of spatial images preferred by sighted individu- als is a visual (visualization) and verbal channel (XY strategy). On the other hand, blind persons tend to use linguistic information (XY strategy) as readily as motor input (tapping strategy) (cf.: Struiksma et al., 2009).

Received September 4, 2013

\section{REFERENCES}

ALEMAN, A., VAN LEE, L., MANTIONE, M.H., VERKOIJEN, I.G., DE HAAN, E.H., 2001, Visual imagery without visual experience: Evidence from congenitally totally blind people. Neuroreport, 12 , 2601-2604.

ARDITI, A., HOLTZMAN, D., KOSSLYN, S.M., 1988, Mental imagery and sensory experience in congenital blindness. Neuropsychologia, 26, 1-12.

ARNO, P., VANLIERDE, A., STREEL, E., WANET-DEFALQUE, M.-C., SANABRIABOHORQUEZ, S., VERAART, C., 2001, Auditory substitution of vision: Pattern recognition by the blind. Applied Cognitive Psychology, 15, 509-519.

BERTOLO, H., PAIVA, T., PESSOA, L., MESTRE, T., MARQUES, R., SANTOS, R., 2003, Visual dream content, graphical representation and EEG alpha activity in congenitally blind subjects. Cognitive Brain Research, 15, 277-284.

CATTANEO, Z., VECCHI, T., 2011, Blind vision. The neuroscience of visual impairment. Massachusetts: The MIT Press.

CATTANEO, Z., VECCHI, T., CORNOLDI, C., MAMMARELLA, I., BONINO, D., RICCARDI, E., PIETRINI, P., 2008, Imagery and spatial processes in blind and visual impairment. Neuroscience and Biobehavioral Reviews, 32, 1346-1360.

CORNOLDI, C., BERTUCCELLI, B., ROCCHI, P., SBRANA, B., 1993, Processing capacity limitations in pictorial and spatial representations in the totally congenitally blind. Cortex, 29, 675689.

CORNOLDI, C., TINTI, C., MAMMARELLA, I.C., RE, A.M., VAROTTO, D., 2009, Memory for an imagined pathway and strategy effects in sighted and in totally congenitally blind individuals. Acta Psychologica, 130, 11-16.

CORNOLDI, C., VECCHI, T., 2003, Visuo-spatial working memory and individual differences. Hove, United Kingdom: Taylor and Francis/Psychology Press. 
HELLER, M.A., 1989, Picture and pattern perception in the sighted and the blind: The advantage of the late blind. Perception, 18, 379-389.

HULL, T., MASON, H., 1995, Performance of blind children on digit span tests. Journal of Visual Impairment \& Blindness, 89, 166-169.

KERR, N.H., DOMHOFF, G.W., 2004, Do the blind literally "see" in their dreams? A critique of a recent claim that they do. Dreaming, 14, 230-233.

KOSSLYN, S.M., 1994, Image and brain. Cambridge, MA: MIT Press.

KOUSTRIAVA, E., PAPADOPOULOS, K., 2012 Are there relationships among different spatial skills of individuals with blindness? Research in Developmental Disabilities, 33, 2164-2176.

KOZHEVNIKOV, M., KOSSLYN, S., SHEPARD, J., 2005, Spatial versus object visualizers: A new characterization of visual cognitive style. Memory \& Cognition, 33, 710-726.

LONG, R.G., GIUDICE, N.A., 2010, Establishing and maintaining orientation for orientation and mobility. In: B.B. Blasch, W.R. Wiener, R.W. Welch (Eds.), Foundations of orientation and mobility, $3 r d$ ed (pp. 45-62). New York: American Foundation for the Blind.

LOOMIS, J.M., KLATZKY, R.L., GIUDICE, N.A., 2013, Representing 3D space in working memory: Spatial images from vision, touch, hearing, and language. In: S. Lacey, R. Lawson (Eds.), Multisensory imagery: Theory \& applications (pp.131-156). New York: Springer.

LOOMIS, J.M., LIPPA, Y., GOLLEDGE, R.G., KLATZKY, R.L., 2002, Spatial updating of locations specified by 3 -d sound and spatial language. Journal of Experimental Psychology: Learning, Memory, and Cognition, 28, 335-345.

LOPES DA SILVA, F.H., 2003, Visual dreams in the congenitally blind? Trends in Cognitive Sciences, 7, 328-330.

MILLAR, S., 1975, Spatial memory by blind and sighted children. British Journal of Psychology, 66, 449-459.

NOORDZIJ, M.L., ZUIDHOEK, S., POSTMA, A., 2006, The influence of visual experience on the ability to form spatial mental models based on route and survey descriptions. Cognition, 100, 321 342 .

NOORDZIJ, M.L., ZUIDHOEK, S., POSTMA, A., 2007, The influence of visual experience on visual and spatial imagery. Perception, 36, 101-112.

PASCUAL-LEONE, A., HAMILTON, R., 2001, The metamodal organization of the brain. Progress in Brain Research, 134, 427-445.
PASQUALOTTO, A., PROUlX, M.J., 2012, The role of visual experience for the neural basis of spatial cognition. Neuroscience and Biobehavioral Reviews, 36, 1179-1187.

PASQUALOTTO, A., SPILLER, M.J., JANSARI, A.S., PROULX, M.J., 2013, Visual experience facilitates allocentric spatial representation. Behavioural Brain Research, 236, 175-179.

PETKOVA, V.I., ZETTERBERG, H., EHRSSON, H.H., 2012, Rubber hands feel touch, but not in blind individuals. PLoS ONE, 7: e35912. doi:10.1371/journal.pone.0035912.

POSTMA, A., ZUIDHOEK, S., NOORDZIJ, M.L., KAPPERS, A.M., 2007, Differences between early-blind, late-blind, and blindfolded-sighted people in haptic spatial-configuration learning and resulting memory traces. Perception, 36, 1253-1265.

POSTMA, A., ZUIDHOEK, S., NOORDZIJ, M.L., KAPPERS, A.M., 2008, Haptic orientation perception benefits from visual experience: Evidence from early-blind, late-blind, and sighted people. Perception \& Psychophysics, 70, 1197 1206.

RAZ, N., STRIEM, E., PUNDAK, G., ORLOV, T., ZOHARY, E., 2007, Superior serial memory in the blind: A case of cognitive compensatory adjustment. Current Biology, 17, 1129-1133.

RÖDER, B., RÖSLER, F., NEVILLE, H.J., 2001, Auditory memory in congenitally blind adults: A behavioral-electrophysiological investigation. Cognitive Brain Research, 11, 289-303.

SCHMIDT, S., TINTI, C., FANTINO, M., MAMMARELLA, I.C., CORNOLDI, C., 2013, Spatial representations in blind people: The role of strategies and mobility skills. Acta Psychologica, 142, 43-50.

STRUIKSMA, M.E., NOORDZIJ, M.L., POSTMA, A., 2009, What is the link between language and spatial images? Behavioral and neural findings in blind and sighted individuals. Acta Psychologica, 132, 145-156.

SZUBIELSKA, M., 2010, Zdolności wyobrażeniowe niewidomych dzieci w zakresie skaningu i rotacji kształtu dotykanych obiektów [The spatial imagery in blind children: Abilities to scan and rotate tactile objects' shapes]. Roczniki Psychologiczne , 13, 145-160.

TOROJ, M., SZUBIELSKA, M., 2011, Prior visual experience, and perception and memory of shape in people with total blindness. British Journal of Visual Impairment, 29, 60-81.

VANLIERDE, A., DE VOLDER, A.G., WANETDEFALQUE, M.-C., VERAART, C., 2003, 
Occipito-parietal cortex activation during visuospatial imagery in early blind humans. NeuroImage, 19, 698-709.

VANLIERDE, A., WANET-DEFALQUE, M.-C., 2004, Abilities and strategies of blind and sighted subjects in visuo-spatial imagery. Acta Psychologica, 116, 205-222.

VANLIERDE, A., WANET-DEFALQUE, M.-C., 2005 , The role of visual experience in mental im- agery. Journal of Visual Impairment \& Blindness, $3,165-178$.

VECCHI, T., 1998, Visuo-spatial imagery in congenitally totally blind people. Memory, 6, 91102 .

WITHAGEN, A., KAPPERS, A.M., VERVLOED, M.P., KNOORS, H., VERHOEVEN, L., 2012, Haptic object matching by blind and sighted adults and children. Acta Psychologica, 139, 261-271.

\title{
STRATÉGIE VYTVÁRANIA PRIESTOROVÝCH REPREZENTÁCII POUŽIVANÝCH NEVIDIACIMI A VIDIACIMI
}

\author{
M. $\mathrm{S} z$ u bi e $1 \mathrm{sk}$ a
}

Súhrn: Ciel'om štúdie bolo skúmat’ stratégie zobrazovania používané nevidiacimi a vidiacimi a ich schopnost' používat' priestorové reprezentácie. Potvrdilo sa, že presnost' výkonu v zobrazovacích úlohách bola podobná u nevidiacich bez akýchkolvvek zrakových spomienok a u vidiacich. Na druhej strane výsledky ukázali odlišnosti v preferovaných stratégiách zobrazovania. Vidiaci častejšie ako nevidiaci používali stratégiu vizualizácie priestorových matíc. Nevidiaci použivali častejšie stratégiu poklepávania. Dodatočná analýza sa zamerala na funkciu systémov pracovnej pamäti pri spracovávaní priestorových podnetov nevidiacimi ako aj vidiacimi. 